\title{
TANTANGAN PERCERAIAN SIPIL BAGI PERKAWINAN KATOLIK: ANTARA HUKUM ILAHI DAN HUKUM MANUSIA
}

\author{
Yohanes Servatius Lon \\ Universitas Katolik Indonesia Santu Paulus Ruteng \\ Jl. A. Yani No. 10 Ruteng Flores, NTT, 86518 \\ yohservatiusboylon@gmail.com
}

\begin{abstract}
Marriage is both as a sacred/divine and social thing. Therefore marriage is part of worship as well as being bound to legal and social aspects. Then marriage is regulated both by a religious and by non-religious institution. This paper explores the different principles regarding divorce of a legal marriage according to Catholic and civil law. Marriage in Catholic law is eternal and there is no principle of divorce. Whereas civil law allows couple to divorce. Catholics' marriages that are legal according to Catholic Church law but divorced by a State Court judge have created many new problems. This study aims to explore the complexity of the challenges facing the Catholic couples. The method of this research is a qualitative. Using a library approach and field study, this study found that there were legal uncertainties and injustices experienced by Catholic couples who were divorced by a state court. This study recommends that there is a need for synergy between state courts and church courts in marital divorce matters. Furthermore, it requires state law that truly respects the autonomy of religious law.
\end{abstract}

Keywords; Divorce, Marriage, Catholic Law, Civil Law

\section{Abstrak}

Perkawinan adalah hal yang sacral/ilahi sekaligus bersifat sosial dan manusiawi. Olehnya perkawinan adalah bagian dari ibadah maupun juga terikat pada aspek hukum dan sosial. Maka perkawinan diatur baik oleh lembaga agama maupun oleh lembaga non agama seperti oleh negara. Penelitian ini mengeksplorasi perbedaan prinsip mengenai perceraian sebuah perkawinan yang sah menurut hukum agama Katolik dan hukum sipil. Perkawinan dalam hukum gereja Katolik bersifat kekal dan tidak ada prinsip perceraian. Sedangkan hukum sipil membolehkan adanya perceraian. Perkawinan Katolik yang sah menurut hukum Gereja Katolik namun diceraikan oleh hakim Pengadilan Negara telah menimbulkan banyak masalah baru. Penelitian ini bertujuan untuk mengeksplorasi kompleksitas tantangan yang dihadapi pasangan Katolik tersebut. Penelitian ini menggunakan desain dan metode kualitatif. Dua hal yang dilakukan yakni analisa dua hukum perkawinan dan pengumpulan data lapangan melalui wawancara mendalam. Studi ini menemukan bahwa ada ketidakpastian hukum dan ketidakadilan yang dialami oleh pasangan Katolik yang diceraikan perkawinanya oleh pengadilan negara. Studi ini merekomendasikan agar perlu sinergisitas antara pengadilan negara dan pengadilan gereja dalam urusan perceraian perkawinan. Selanjutnya dibutuhkan hukum negara yang sungguh-sungguh menghargai otonomi hukum agama namun sekaligus menghormati hak-hak warga Negara.

Kata Kunci; Perceraian, Perkawinan, Hukum Gereja, Hukum Negara. 


\section{PENDAHULUAN}

Studi-studi mengenai perkawinan menarik perhatian banyak ahli dewasa ini. Kajian mereka memperlihatkan bahwa bagi masyarakat, perkawinan adalah suci atau sakral. Perkawinan bukan hanya menjadi urusan manusia melainkan juga bagian dari ibadah. Pemikiran mengenai hal ini hampir ada pada semua agama dan kebudayaan di dunia. Di dalam konsep ini, perkawinan melibatkan faktor ilahi dan berurusan dengan agama. Tidak ada perkawinan yang terjadi tanpa melibatkan lembaga agama. Setiap agama mempunyai aturan tentang perkawinan termasuk ritual keagamaan untuk melegalkan dan menyucikannya. Setiap perkawinan umumnya ditandai adanya upacara pernikahan di mana dilambungkan doa syukur dan permohonan untuk para pengantin sekaligus ada legalisasi pernikahan oleh pejabat agama dari mempelai dengan dihadiri para saksi atau wali. Ritual dan hukum keagamaan sesungguhnya menghadirkan aspek keilahian dari suatu perkawinan ${ }^{1}$.

Setiap hukum agama tentunya bertujuan untuk melindungi perintah Tuhan bagi manusia. $^{2}$ Demikian pula dalam konteks perkawinan, hukum agama juga mempromosikan kehendak Tuhan. Menyadari krusialnya aspek keilahian dalam sebuah perkawinan, Undang-undang Republik Indonesia No 1 tahun $1974^{3}$ tentang perkawinan dengan tegas mengatakan bahwa perkawinan yang sah adalah perkawinan yang dilakukan menurut hukum masing-masing agama. Walaupun aturan ini kerap diperdebatkan, namun hal ini sudah diterima umum di Negara Indonesia. Apalagi bangsa Indonesia menganut Pacasila sebagai dasar Negara dengan Sila Pertama, Ketuhanan Yang Maha Esa, sudah sangat eksplisit memperlihatkan pengakuan aspek ilahi dari aneka aspek kehidupan, termasuk perkawinan.

Di sisi lain perkawinan juga adalah urusan manusiawi, yang melibatkanaspek personal, aspek hukum dan administratif ${ }^{4}$. Setiap perkawinan terjadi antara pribadi namun juga membutuhkan campur tangan keluarga dan teman serta tetangga. Setiap perkawinan harus dikukuhkan secara hukum positif, yaitu hukum yang dibuat

\footnotetext{
1 Dewi Riana Nyoman dan Hilda Sudhana, "Hubungan Antara Komunikasi Interpersonal Pasutri dengan Keharmonisan dalam Pernikahan".Jurnal Psikologi Udayana 1. No. 1 (2013): hlm. 22-31

2 Sulton Habib Asnawi, Habib Shulton,"Hak Asasi Manusia Islam dan Barat: Studi Kritik Hukum Pidana Islam dan Hukuman Mati”.Supremasi Hukum1. No. 1 (2012): hlm. 25-48

3 Undang-undang Republik Indonesia No 1 tahun 1974 tentang Perkawinan Pasal 2

4 Itsnaatul Lathifah, "Pencatatan Perkawinan: Melacak Akar Budaya Hukum dan respon Masyarakat Indonesia terhadap Pencatatan Perkawinan". Jurnal Pemikiran Hukum. 3 No. 1 (2015): hlm. 43:53
} 
manusia seperti hukum adat dan hukum positif. Pasal 2 Undang-undang Perkawinan tahun 1974, misalnya menegaskan bahwa perkawinan itu sah jika dicatat sesuai hukum yang berlaku. Dalam konteks ini perkawinan harus mengikuti ketentuan dan aturan hukum positif yang dibuat manusiadan juga melibatkan lembaga pernikahan yang dibuat manusia. ${ }^{5}$ Hukum positif manusia pada umumnya disusun untuk mempromosikan dan melindungi kepentingan dan hak asasi manusia. Dengan hukum positif, pasangan dan anak-anak yang dilahirkan dari perkawinan yang sah juga mendapat perlindungan hukum dan sejumlah hak sebagai warga negara.

Dewasa ini perkawinan yang diyakini "suci"tergerus dan terancam oleh berbagai kasus perceraian. Apalagi perceraian di Indonesia sudah meresahkan kehidupan keluarga dan jika dibandingkan dengan negara lain maka Indonesia sudah menempati urutan tertinggi se Asia Pasifik.Data dari Kementrian Agama RI dan Badan Pusat Statistik menunjukkan adanya peningkatan kasus perceraian selama periode 2013-2018. Pada tahun 2013 dilaporkan ada 324247 kasus perceraian, 344237 kasus pada tahun 2014, 347.256 kasus tahun 2015, 365.530 kasus tahun 2016, 374.520 tahun 2017, dan 418.200 kasus tahun $2018{ }^{6}$

Fenomena perceraian sesungguhnya menggugat hakikat perkawinan yang memiliki unsur manusia dan unsur ilahi. Ketika terjadi perceraian, ada hal yang dengan mudah dibatalkan terutama hal-hal yang berkaitan dengan aspek manusia. Namun ketika menyentuh aspek keilahian sebuah perkawinan, maka tidak mudah dibayangkan cara untuk membatalkannya. Lumme ${ }^{7}$ menulis:

Akan tetapi ketika memasuki dunia empiris, penerapan hukum (lawenforcement) baik norma hukum positif (negara) maupun norma hukum agama di bidang perceraian menjadi masalah yang kompleks.

Dalam banyak kasus, pertimbangan perceraian lebih didasarkan pada aspek relasi personal suami isteri ${ }^{8}$ dan kurang mempertimbangkan aspek keagamaan.

\footnotetext{
${ }^{5}$ H. Faradz, "Tujuan dan Manfaat Perjanjian Perkawinan”. Jurnal dinamika Hukum 8, No. 3 (2008): hlm. 249-252

${ }^{6}$ Badan Pusat statistik 2019. www.bps.go.id

7 Andreas Lumme, "Norma Hukum Agama Katolik di Bidang Perceraian dan Konflik Penerapannya di Pengadilan Bagi Suami Isteri”, Jurnal Hukum Pro Justisia, Vol. 25 (2007):

8 Dewi Riana Nyoman dan Hilda Sudhana, Op.Cit.
} 
Persoalan perceraian menjadi rumit ketika hukum suatu agama seperti hukum agama Katolik melarang terjadinya perceraian. ${ }^{9}$ Lebih rumit lagi karena Undangundang No 1 Tahun 1974 tentang Perkawinan memberikan lembaga agama otonomi hanya untuk pengesahan perkawinan sementara kewenangan untuk mengesahkan perceraian hanya berada pada otonomi negara (hakim pengadilan negara). Di sini ada dua lembaga berbeda yang memiliki kewenangan dalam urusan perkawinan. Konsekuensinya, ketika ada pasangan Katolik yang gagal dengan perkawinannya, mereka datang kepada pengadilan negara untuk urusan perceraiannya.

Pemberian surat cerai kepada pasangan Katolik tentunya tidak kurang menimbulkan masalah baru. Kewenangan memutuskan perceraian pada hakim sesungguhnya tidak menjamin seorang Katolik untuk dapat menikah lagi dengan orang baru di dalam Gereja Katolik. Namun di sisi lain, larangan perceraian agama secara hukum tidak serta merta membuat pasangan yang telah dinikahkan menurut hukum agama Katolik bisa bertahan di dalam perkawinan mereka yang bermasalah. Maka, adanya hukum perceraian sipil dalam arti tertentu bisa menjadi alternatif bagi pasangan Katolik untuk bercerai secara hukum sipil yang manusiawi.

Berdasarkan permasalahan tersebut, penelitian ini bertujuan mengeksplorasi kompleksitas perceraian perkawinan bagi pasangan suami isteri Katolik. Fokus perhatiannya terutama untuk menganalisa tantangan dalam menerapkan dan mengimplementasi keputusan perceraian oleh pengadilan negara. Pertanyaannya adalah: Bagaimanakah tantangan yang dihadapi pasangan yang cerai secara hukum negara namun tetap sah menurut hukum Agama (Gereja)? Apakah perceraian sipil memudahkan perkawinan dengan orang pasangan yang baru? Apakah surat keputusan cerai di pengadilan sipil harus diakui dan diikuti oleh lembaga agama? Apakah dengan surat keputusan pengadilan tersebut, seseorang dapat menikah lagi menurut aturan agamanya atau kepercayaannya? Bagaimana perbedaan kedua hukum (agama Katolik dan sipil) berdampak pada pasangan yang ingin atau sudah bercerai?

9 Yohanes S. Lon. Hukum Perkawinan Sakramental dalam Gereja Katolik. Yogyakarta: Penerbit PT Kanisius, 2019. Lihat juga, Andreas Lume. Op.Cit. Lihat juga. Yohanes S. Londa dan Fransiska Widyawati, "Bride-Wealth: Is There Respect for Women in Manggarai?“ Humaniora, 30 No. 3 (2018):271-278. DOI: https://doi.org/10.22146/jh.v30i3.29216 


\section{METODHE PENELITIAN}

Penelitian ini menggunakan pendekatan kualitatif. Ada dua hal utama yang dilakukan yakni studi kepustakaan dan lapangan. Untuk studi kepustakaan, hal yang dilakukan adalah melakukan kajian dan analisa perbandingan hukum perkawinan mengenai perceraian menurut hukum sipil (hukum negara) dan hukum Gereja Katolik. Pada bagian ini akan dijelaskan secara rinci aturan tentang perceraian sesuai dengan ketentuan yang berlaku untuk masing-masing institusi. Selanjutnya, dibuat perbandingan yang menunjukkan persamaan dan perbedaan antara hukum agama Katolik dan hukum Negara Republik Indonesia. Perbandingan dibuat terutama pada aspek-aspek dan prinsip-prinsip penting perceraian menurut masing-masing hukum perkawinan. Hasil perbandingan (perbedaan) antara keduanya akan dianalisa untuk menemukan dampaknya bagi pasangan suami isteri Katolik.

Untuk studi lapangan, para peneliti menggunakan pendekatan kualitatif dengan melakukan in depth interview (wawancara mendalam). Repsondennya adalah 10 keluarga yang dipilih secara sengaja (purposive). Keluarga-keluarga tersebut adalah mereka yang memunhi tiga kriteria berikut: 1) mereka telah pernah melakukan pernikahansecara sah menurut hukum agama Katolik, 2) perkawinan tersebut telah diceraikan secara sahdalam pengadilan sipil, dan 3) Mereka telah tinggal bersama pasangan yang baru.Wawancara terhadap mereka dilakukan secara terpisah di tempat mereka masing-masing. Kepada mereka diberikan beberapa pertanyaan proses legalisasi perkawinannya di dalam Gereja Katolik, kisah perceraiannya oleh hakim di pengadilan negara, kehidupannya dengan pasangan yang baru dan berbagai tantangan yang dihadapinya bersama pasangan yang baru.

Selain itu, penelitian ini juga menggunakan pengamatan terhadap kehidupan pasangan yang sudah menerima keputusan cerai dari pengadilan. Pengamatan dilakukan untuk memahami realitas kehidupan keluarga yang bercerai serta bagaimana reaksi serta sikap keluarga besar dan komunitas Gereja terhadap mereka. Keuntungannya adalah bahwa para peneliti itu sendiri adalah orang-orang Katolik dan oleh karena itu pemahaman mereka tentang ajaran Katolik lebih luas dan lebih mudah. Sudut pandang yang digunakan "dari dalam" tentu tidak mengurangi 
interpretasi dan jarak yang masuk akal dari apa yang dipelajari. Dengan demikian validitas penelitian tetap dapat dipertahankan.

\section{PEMBAHASAN DAN ANALISIS}

\subsection{Hukum Gereja Katolik tentang Perceraian}

Menurut Hukum Gereja Katolik, perkawinan tidak saja merupakan tindakan manusia dalam rangka membangun cinta dan relasi personalnya. Perkawinan terutama merupakan karya ciptaan dan rencana Allah. Hal ini sesuai dengan isi Kitab Suci khususnya tentang penciptaan (Kejadian 1, 26-28). Sejak awal mula penciptaan manusia, Allah menetapkan perkawinan. Allah adalah kasih dan karena kasihNya Allah menciptakan manusia, laki-laki dan perempuan sesuai dengan gambarNya (Kejadian 1, 27). Tidak baiklah kalau mereka hidup sendirian (Kejadian 2,11). Injil Markus 10, 6-8 menegaskan: "Sebab pada awal dunia, Allah menjadikan mereka lakilaki dan perempuan, sebab itu laki-laki akan meninggalkan ayahnya dan ibunya dan bersatu dengan isterinya sehingga keduanya menjadi satu daging. Demikianlah mereka bukan lagi dua, melainkan satu". ${ }^{10}$

Perkawinan sesungguhnya ditetapkan sebagai perintah Allah atau hukum ilahi. Allah menetapkan persekutuan suami isteri sebagai asal mula dan dasar masyarakat manusia. Allah mewariskan dalam kodrat manusia (laki-laki dan perempuan), kebutuhan, panggilan, dan tanggungjawab untuk mengasihi dan hidup dalam persekutuan personal sebuah perkawinan. ${ }^{11}$ Perkawinan adalah bagian dari iman dan ibadah. Maka melaksanakan perkawinan adalah cara manusia menjawab panggilan Allah dan bagian dari tanggung jawab sebagai mahluk beragama.

Selanjutnya, prinsip perkawinan Katolik adalah monogami dan tak terceraikan. Artinya, agama Katolik juga melarang perceraian. Hal ini sesuai dengan perkataan Allah sebagaimana dikatakan dalam Kitab Malaiki 2, 16a: "Sebab Aku membenci perceraian, firman Tuhan, Allah Israel”.Pernyataan ini dipertegas lagi oleh Yesus sendiri dalam teks Kitab Mateus 19, 3-6: "Demikianlah mereka bukan lagi dua

10 Teks Kitab Suci diambil dari Alkitab-Deutrokanonika, Lembaga Biblika Indonesia.

11 Lon S. Yohanes. Hukum Perkawinan Sakramental dalam Gereja Katolik. Yogyakarta (2019),Yogayakarta: PT Kanisius. Lihat juga, Yohanes S. Lon, "Increasing the Knowledge and Awareness of the People of Ruteng Diocese in Canon Law" Randang Tana-Jurnal Pengabdian kepada Masyarakat 2 No. 1 (2019): 1-9; Widyawati, Fransiska, Catholics in Manggarai, Flores, Eastern Indonesia, Globethics.net 
melainkan satu. Karena itu apa yang telah dipersatukan Allah, tidak boleh diceraikan manusia". Yesus menegaskan perkawinan sebagai hasil ketetapan hukum ilahi dan olehnya perceraian dilarang. ${ }^{12}$ Larangan perceraian ini dikukuhkan dan didasarkan pada pemikiran teologis tentang cinta perkawinan yang menggambarkan hubungan kasih setia Tuhan terhadap umatNya dan kasih setia Kristus terhadap GerejaNya. Relasi cinta suami isteri menjadi simbol hubungan kesetiaan antara Allah dan manusia.

Keyakinan teologis ini dielaborasi secara yuridis dalam Kitab Hukum Kanonik (KHK-Canon Law). ${ }^{13}$ KHK adalah kitab hukum yang dimiliki gereja Katolik. Kitab Hukum Kanonik (KHK) pasal 1056, 1060 dan 1141 mengatur mengenai perkawinan. Pasal 1056 menyatakan sifat indisolubilitas (tak-dapat diputuskan) sebagai ciri hakiki dari perkawinan Katolikyang sakramental. Perkawinan sakramental adalah perkawinan yang sah antara orang-orang yang dibaptis baik dalam Gereja Katolik maupun di luar Gereja Katolik. Tidak ada perkawinan orang Katolik yang tidak merupakan sebuah sakramen.

Selanjutnya Pasal $1060^{14}$ memberikan perlindungan hukum terhadap setiap perkawinanorang Katolik. Dikatakan: "Perkawinan mendapat perlindungan hukum; karena itu dalam keragu-raguan haruslah dipertahankan sahnya perkawinan, sampai dibuktikan kebalikannya". Di sini perkawinan Katolik yang sah harus tetap dipertahankan dan tidak boleh dibatalkan atau diputuskan oleh siapapun. Prinsip ini dipertegas olehPasal 114115yang berbunyi: "Perkawinan ratum et consummatum tidak dapat diputus oleh kuasa manusiawi manapun dan atas alasan apapun, selain oleh kematian".

Kententuan hukum positif ini menegaskan lebih lanjut tentang perkawinan yang tidak terceraikan. Tidak ada satu kuasa manusiawi manapun pun baik pribadi maupun lembaga yang dapat menceraikan perkawinan Katolik yang sah dan sakramen. Pasangan suami isteri juga tidak mempunyai kewenangan untuk memutuskan perkawinan mereka karena telah diikat oleh Tuhan sendiri. Demikian juga setiap lembaga yang dibentuk oleh manusia tidak dapat menceraikan

\footnotetext{
12 Andreas Lumme, Op.Cit.

13 Kitab Hukum Kanonik (Codex Iuris Canonici) 1983, Jakarta: Konferensi Waligereja Indonesia

14 Pasal 1060 Kitab Hukum Kanonik (Codex Iuris Canonici), Ibid.

15 Pasal 1141 Kitab Hukum Kanonik (Codex Iuris Canonici), Ibid.
} 
perkawinan yang sama. Singkatnya, setiap perkawinan Katolik tidak bisa diceraikan dengan sewenang-wenang oleh setiap orang termasuk pasutri itu sendiri (kewenangan internal) ataupun lembaga manapun (kewenangan eksternal). Sekali menikah untuk selama-lamanya, ikatan itu terjadi sampai mati.

Pada pihak lain Hukum Gereja Katolik juga berbicara tentang perkawinan yang tidak sah. Ditegaskan bahwa perkawinan yang tidak sah adalah perkawinan yang mempunyai cacat konsensus (Pasal 1095-1107) ${ }^{16}$, perkawinan yang mempunyai halangan untuk menikah (pasal 1083-1094) ${ }^{17}$, dan perkawinan yang mempunyai cacat forma kanonika (pasal 1108-1123)18. Kewenangan untuk membatalkan perkawinan tersebut diberikan kepada lembaga pengadilan Gereja sendiri (pasal 1673) ${ }^{19}$. Selanjutnya Hukum Gereja Katolik memberikan kewenangan kepada Paus untuk memutuskan perkawinan non consummatum (pasal 1142) ${ }^{20}$ dan perkawinan yang sah tapi tidak sakramental, yaitu perkawinan antara orang yang dibaptis dengan yang tidak dibaptis ataupun perkawinan antara orang-orang yang tidak dibaptis (pasal 1143)21. Hukum Gereja Katolik membuat pemilahan antara perkawinan yang sah dan tidak sah, perkawinan yang sakramental dan tidak sakramental. Kuasa manusia seperti lembaga pengadilan Gereja dan Paus hanya berwenang untuk membatalkan perkawinan yang tidak sah dan tidak sakramental. ${ }^{22}$

\subsection{Aturan Hukum Positif Perkawinan terkait Hukum Perkawinan mengenai Perceraian}

Perkawinan di Indonesia pada dasarnya diatur oleh Undang-undang Perkawinan Republik Indonesia Nomor 1 Tahun 1974 tentang Perkawinan. Dalam Pasal 1 Undang-undang tersebut perkawinan dirumuskan sebagai suatu ikatan lahir dan batin antara seorang pria dan seorang wanita dengan tujuan untuk membentuk keluarga yang bahagia dan kekal berdasarkan ke-Tuhanan yang Maha Esa.

\footnotetext{
16 Pasal 1095-1107 Kitab Hukum Kanonik (Codex Iuris Canonici), Ibid.

17 Pasal 1083-1094 Kitab Hukum Kanonik (Codex Iuris Canonici), Ibid.

18 Pasal 1108-1123 Kitab Hukum Kanonik (Codex Iuris Canonici), Ibid.

19 Pasal 1673 Kitab Hukum Kanonik (Codex Iuris Canonici), Ibid.

20 Pasal 1142 Kitab Hukum Kanonik (Codex Iuris Canonici), Ibid.

${ }^{21}$ Pasal 1143 Kitab Hukum Kanonik (Codex Iuris Canonici), Ibid.

22 Dalam Gereja Katolik dibedakan pengertian perceraian dari pembatalan (anulasi). Perceraian terjadi pada perkawinan yang sah; sedangkan pembatalan terjadi pada perkawinan yang tidak sah
} 
Perkawinan terjadi antara seorang pria dan seorang wanita serta mengikat mereka satu sama lain secara utuh dengan mencakup aspek lahiriah dan rohaniah. Perkawinan menjadi satu-satunya lembaga dimana seorang pria dan wanita dapat membentuk suatu rumah tangga atau keluarga. Selanjutnya pasal 2 Undang-undag tersebut dicantumkan kewenangan lembaga agama terhadap perkawinan. Satu perkawinan menjadi sah apabila dilaksanakan menurut agama dan kepercayaannya masing-masing. Konsekuensinya tidak ada perkawinan yang sah di luar hukum masing-masing agamanya dan kepercayaannya itu (Pejelasan pasal 2 ayat 1 UU Perkawinan).

Kemudian dalam Undang-undang tersebut juga dinyatakan bahwa perkawinan dapat putus karena tiga alasan yaitu 1) kematian, 2) perceraian, dan 3) putusan pengadilan (pasal 38). Khusus tentang perceraian diuraikan secara rinci dalam Pasal 23 Undang-undang tersebut. Dikatakan bahwa perkawinan yang sah dapat dibatalkan atau diceraikan atas permintaan a) para keluarga dalam garis keturunan lurus ke atas dari suami atau isteri; b) Suami atau isteri; c) Pejabat yang berwenang hanya selama perkawinan belum diputuskan; d) Pejabat yang ditunjuk dalam ayat (2) Pasal 16 Undang-undang ini dan setiap orang yang mempunyai kepentingan hukum secara langsung terhadap perkawinan tersebut, tetapi hanya setelah perkawinan itu putus. Pasal ini tentunya memberi ruang kepada suami dan isteri untuk menceraikan pasangannya. Sementara dalam pasal-pasal yang lain (pasal 28, 38-40)23 diberi kewenangan kepada Hakim (pihak eksternal) untuk membuat keputusan tentang perceraian. Dalam berbagai sidang perceraian, suami atau isteri hanya menjadi pemohon untuk terlaksananya sebuah putusan perceraian, bahkan hak ikrar talak yang menjadi hak suami tidak dapat dilaksanakan jika tidak mendapat izin dari hakim di pengadilan.

Maka perceraian secara resmi harus dilakukan di depan sidang Pengadilan Agama (Pasal 39). Sebelum melakukan sidang perceraian tersebut Pengadilan Agama diwajibkan untuk berusaha mendamaikan pasangan yang berkonflik. Jika sulit didamaikan maka sidang perceraian dapat dilanjutkan. Perceraian dapat diputuskan berdasarkan alasan 1) salah satu pihak berbuat zinah atau menjadi pemabuk,

23 Pasa 28,38-40 Undang-undang Perkawinan Republik Indonesia Nomor 1 Tahun 1974 tentang Perkawinan. 
pemadat, penjudi dan lain sebagainya yang sukar disembuh; 2) salah satu pihak meninggalkan pihak lain selama dua tahun berturut-turut tanpa izin pihak lain dan tanpa alasan yang sah atau karena hal lain di luar kemampuannya, 3) salah satu pihak mendapat hukuman penjara 5 (lima) tahun atau hukuman yang lebih berat setelah perkawinan berlangsung, 4) salah satu pihak melakukan kekejaman atau penganiayaan berat yang membahayakan pihak lain, 5) salah satu pihak mendapat cacat badan atau penyakit dengan akibat tidak dapat menjalankan kewajibannya sebagai suami atau isteri, 6) antara suami dan isteri terus menerus terjadi perselisihan dan pertengkaran dan tidak ada harapan akan hidup rukun lagi dalam rumah tangga, 7) suami melanggar taklik talak, 8) peralihan agama atau murtad yang menyebabkan terjadinya ketidakrukunan dalam rumah tangga (Penjelasan pasal 39). ${ }^{24}$

\subsection{Tantangan Keluarga Katolik yang Cerai Sipil}

Memperhatikan karakteristik dari kedua hukum ini mengenai perceraian, tentu saja ada perbedaan yang sangat signifikan. Perbedaan ini membawa konsekuensi bagi bagi pasangan maupun bagi hukum itu sendiri. Gereja Katolik dengan tegas melarang perceraian sedangkan hukum sipil mengijinkan perceraian.

Walaupun perceraian dilarang dalam Gereja Katolik, namun ada banyak kasus perceraian yang terjadi pada keluarga Katolik. Bahkan sebagian dari mereka telah memproseskan masalah perkawinannya kepada pengadilan negara dan menerima putusan perceraian. Dalam banyak kasus pasangan suami isteri tersebut juga telah tinggal dengan pasangan suami atau isteri yang baru, walaupun tidak diresmikan menurut hukum agama (aturan gereja). Penelitian ini mengidentifikasi sejumlah dampak dan tantangan yang dialami oleh pasangan Katolik sebagaimana diuraikan di bawah ini. Nama para responden sengaja disamarkan untuk menjaga privasi mereka dan sesuai dengan kesepakatan saat wawacara dilakukan.

Tantangan pertama yang dialami oleh pasangan suami isteriKatolikyang cerai menuruthukum negara adalah penolakan pengakuan dari otoritas Gereja Katoliktentang perceraian tersebut. A dan K, misalnya, bercerita bahwa ketika

24 Pasal 39 Undang-undang Perkawinan Republik Indonesia Nomor 1 Tahun 1974 tentang Perkawinan. 
mereka mendapat surat keputusan cerai dari pengadilan negeri setempat, mereka menghadap dan menyampaikan hal itu kepada pemimpin agamanya (pastor paroki). Mereka agak terkejut ketika pastor parokinya membuat pernyataan bahwa surat keputusan perceraianitu tidak diakui dalam Gereja Katolik. Surat keputusan tersebut tidak dapat digunakan untuk kepentingan urusan pernikahan dengan orang baru di dalam GerejaKatolik. Bahkan pastor menegaskan kepadanya bahwa pernikahan mereka dengan pasangan yang lama masih sah. Olehnya mereka tidak dapat melakukan pernikahan yang baru di dalam gereja Katolik. Pada saat itu A dan K merasa terpukul dan pupus harapannya untuk menikah dengan orang baru dalam Gereja Katolik.

Pasangan lain, $\mathrm{C}$ dan $\mathrm{T}$, dalam pengakuannya, mengatakan bahwa setelah mereka mendapat surat perceraian dari pengadilan Negeri. Atas surat itu, mereka langsung mengambil isteri/suami yang baru. Mereka tinggal bersama dalam satu rumah sebagai keluarga baru. Tentunya kebersamaan mereka belum diakui dan disahkan dalam Gereja Katolik. Mereka secara jujur mengatakan bahwa kadang-kadang mereka merasa kurang nyaman dengan kehidupan bersama yang demikian. Seringkali muncul pemikiran bahwa mereka hidup secara"kumpul kebo" karena belum disahkan oleh lembaga manapun. $\mathrm{C}$ yang sudah lima tahun hidup bersama laki-laki yang baru, misalnya pernah mengungkapkan sebagai berikut: "Pada mulanya saya mengabaikan perasaan yang mengganggu kenyaman hidup kami. Namun ketika kami mempunyai anak, saya pun mulai serius memikirkan kebersamaan kami sebab anak-anak kami membutuhkan akte kelahiran".

Responden lain, B, G, Hbercerita bahwa mereka terpaksa memutuskan untuk meminta pengesahan perkawinan pada agar agama lain mendapat surat nikah. Ada juga si G yang sudah tinggal bersama perempuan lain lebih dari 8 tahunadalah sebagai berikut: "saya terpaksa mengurus nikah di Gereja lain (Gereja Protestan) demi memperoleh akte nikah. Dengan akte nikah tersebut saya dapat menjadi calon anggota DPRD."Ketika ditanyakan kepada B, G, dan H tentang motivasi menikah pada agama lain maka jawaban mereka terkait dengan hak sipil mereka sendiri dan juga hak sipil dari anak-anak. Semua mereka menegaskan bahwa terpaksa hal itu dilakukan. "Saya tahu, apa yang aku lakukan adalah sesuatu yang tidak jujur, namun 
saya yakin, Tuhan Yesus memahami dan memaafkan saya”, ungkap si B yang telah 14 tahun bercerai dengan isterinya dan sekarang tinggal bersama perempuan lain.

Lain lagi dengan kasus dari M,N dan O. Mereka terpaksa memutuskan untuk keluar dari Gereja Katolik dan pindah ke agama yang lain. Menurut mereka, mereka tidak mempunyai pilihan lain selain pindah agama. Di satu sisi mereka masih mau menjadi Katolik namun di sisi lain perkawinan mereka tidak mendapat tempat di dalamnya. Jika mereka tidak pindah agama maka hidup mereka dirasakan kurang lengkap. Mereka macamnya berada di antara Katolik dan non Katolik. Kata si M: "Mau disebut Katolikjuga tidak; mau disebut non Katolik juga tidak". 0 bercerita bahwa pada mulanya dia merasakan sungguh berat untuk pindah agama. Ada banyak hal dipikirkan termasuk dikucilkan dari keluarga besar dan komunitas Gereja Katolik. Sudah sejak kecil saya hidup dan berdoa secara Katolik. Namun demi hak sipil saya dan suaminya serta demi menjamin masa depan anaknya, ia terpaksa pindah agama. Ia mengaku hal itu dialami sebagai yang sungguh berat. Ia berterus terang, bahwa pada mulanya ia berpindah agama secara diam-diam. Ia tidak memberitahu siapapun kecuali suaminya yang baru.

Selanjutnya $\mathrm{W}$ dan $\mathrm{P}$ mengakui bahwa tantangan berat yang dialaminya adalah munculnya perasaan "hidup dalam dosa". Ketika mereka resmi cerai dengan mantan suami mereka, mereka langsung menerima dan tinggal bersama laki-laki lain. Mereka tahu dengan berbuat demikian mereka melanggar aturan agama, aturan Gereja Katolik. Karena itu mereka merasa bahwa mereka telah tidak taat kepada Tuhan. Ada perasaan bersalah dan berdosa di dalam dirinya. Mereka berpikir bahwa hidup perkawinanya yang baru atau hidup bersama orang lain yang tidak diresmikan Gereja dianggap sebagai dosa perzinahan. Apalagi ketika mereka mengikuti kegiatan Misa di Gereja, mereka tidak diperbolehkan untuk menerima komuni kudus. Responden lainnya, W yang sudah dua tahun bercerai dengan isterinya mengaku bahwa dulu sangat setia ke Gereja pada setiap hari Minggu. Namun setelah ia bercerai dengan isterila yang lama dan kemudian saya tinggal bersama perempuan lain, ia tidak lagi ke Gereja. Masalahnya, ketika ia di Gereja muncul perasaan berdosa dalam dirinya. 
Tantangan lain yang dihadapi oleh pasangan Katolik yang perkawinannya diceraikan dalam pengadilan negara yaitu berkaitan dengan status hukumdari pernikahannya dengan pasangan yang baru.Pasangan B-I menceritakan kasus perkawinan mereka. B adalah seorang lelaki yang awalnya menikah secaraKatolik dengan S dan juga mendaftarkan pernikahan mereka secara sipil (negara bagian). Namun, setelah beberapa tahun keduanya memutuskan untuk berpisah karena mereka tidak dapat mempertahankan pernikahan. Keduanya kemudian melakukan perceraian sipil. Pengadilan telah mengabulkan permintaan perceraian mereka. Jadi B kemudian bertemu dengan I, yang sekarang menjadi istrinya. Namun, B dan I tidak bisa menikah di Gereja Katolik, karena Gereja Katolik tidak mengizinkan perceraian. Akibatnya, hingga sekarang B-I hanya bisa hidup bersama tanpa status hukum yang jelas. Mereka juga tidak dapat mendaftarkan perkawinan sipil karena pencatatan sipil hanya dapat dilakukan jika ada akta nikah resmi dari agama. Jadi status mereka pada Kartu Tanda Penduduk (KTP) juga jelas. Keduanya merasa sangat sedih dengan situasi ini.

Selain itu, ada banyak efek negatif bagi anak yang lahir dari perkawinan dengan pasangan yang baru. Dalam beberapa kasus, dimana pemimpin agamanya sangat kaku, ada pemimpin yang menyulitkan anak dari pasangan yang tidak menikah sah untuk mendapatkan pelayanan rohani misalnya untuk dibaptis atau menerima sakramen lain di dalam gereja Katolik. Hal ini sebenarnya tidak boleh demikian. Karena Gereja pada dasarnya tidak memberikan sanksi kepada anak dari hasil perkawinan di luar perkawinan sah menurut Gereja Katolik. Hanya saja, ada pemimpin agama yang sangat ketat dan membuat aturan menjadi sangat kaku dan seenak hatinya.

R pernah berkisah sebagai berikut: "Ketika saya berpisah dengan mantan isteri saya pada tahun 2009, saya langsung hidup bersama dengan isteriku yang sekarang. Dari hubungan tersebut, lahirlah dua orang anak: yang sulung lahir tahun 2010 dan yang kedua lahir tahun 2012. Sebagaimana biasanya dalam keluarga Katolik, setiap anak yang baru lahir dibawa ke pastoran untuk menerima sakramen pembaptisan dan selanjutnya dicatat dalam buku kelahiran. Saya sangat terkejut ketika pastor parokiku tidak melayani permintaan tersebut. Anak saya yang pertama tidak bisa dicatat dalam buku kelahiran orang Katolik. 
Saya sedih".Lebih tragis lagi yang dialami oleh si N. Dia menceritakan bahwa anaknya mengalami kesulitan masuk sekolah karena tidak mempunyai akte kelahiran. Anaknya tidak mempunyai akte kelahiran karena di dalam surat keterangan kelahiran yang dikeluarkan paroki, dicantumkan bahwa anaknya lahir dari orang tua yang perkawinannya ilegal (tidak sah).

Selain kesaksian responden-responden ini, ada juga beberapa responden yang senang dengan hukum perkawinan sipil yang memungkinkan adanya perceraian. Manakala sebagai orang Katolik, Gereja Katolik tidak mengijinkan perceraian, mereka bisa mengajukan perceraian sipil sehingga mereka bisa "melepaskan diri dari masalah perkawinan dan dari pasangan lama mereka. Dengan ini pula, untuk beberapa urusan administrasi negara, yang tidak terkait dengan administasi gereja, mereka bisa mendapatkan haknya. Sebagai contoh, pasangan D-A yang keduanya Aparatur Sipil Negara (ASN), tidak dapat mempertahankan perkawinan mereka secara Katolik bisa menikah lagi dengan pasangan baru yang beda agama setelah mendapatkan akta perceraian dari segi sipil. Hanya saja, perpindahan agama ke agama pasangan baru agar bisa menikah secara sipil dan agama baru adalah konsekuensi lanjutnya. Hal ini walaupun mungkin menjadi solusi namun tentu saja juga problematis. Demikian pula pasangan yang ingin bercerai walaupun tidak menikah dengan pasangan baru, akan merasa lebih nyaman kalau sudah memiliki status legal perceraian (sipil), dengan begitu mereka bisa menata hidupnya sendirisendiri dan bisa mengatur hak dan kewajiban yang berkaitan dengan anak-anak mereka.

Proses unifikasi hukum di Indonesia sangatlah kompleks karena melibatkan berbagai hukum dari ribuan suku, agama, ras, budaya dan sebagainya.Proses tersebut menjadi makin rumit tatkala ada perbedaan dan pertentangan antara hukum yang satu dengan yang lain. Studi ini dengan jelas memperlihatkan perbedaan aturan tentang perceraian antara hukum agama Katolik dan hukum Negara Kesatuan Republik Indonesia (NKRI). Hukum Gereja Katolikdengan tegas melarang perceraian sementara Hukum negara memberi ruang untuk terjadinya perceraian dan bahkan memberi kewenangan pada hakim pengadilan untuk memutuskan sebuah perceraian. Perbedaan tersebut telah menyebabkan munculnya berbagai tantangan 
yang dihadapi oleh pasangan Katolikyang perkawinannya sah menurut hukum Gereja namun telah diceraikan oleh hakim dalam pengadilan sesuai dengan hukum negara.

Pertanyaan pun muncul berkaitan dengan status hukum dari perkawinan orang Katolik yang diceraikan menurut hukum negara. Di satu sisi perkawinan ini tetap diakui sah menurut hukum Gereja Katolik sebab menurutpasal 1 Undang-undang No 1 tahun 1974 tentang Perkawinan, perkawinan yang sah adalah perkawinan yang dilaksanakan sesuai dengan aturan agamanya. Konsekuensinya, jika aturan agama tetap mengakuinya sah, maka perkawinan tersebut juga diakui sah oleh negara. Di sisi lain, pengadilan resmi negara telah memutuskan perceraian terhadap perkawinan tersebut. Sesuai pasal 28, 38-40 Undang-undang yang sama, pengadilan memilikikewenangan untuk memutus-ceraikan sebuah perkawinan. Jadi, dengan putusan tersebut, perkawinan itu menjadi tidak sah lagi.

Situasi perkawinan yang sah menurut hukum Gereja Katolik namun tidak sah menurut Hukum negara merupakan sebuah ketidakpastian hukum.Situasi seperti ini sesungguhnya melawan inti hakikat sebuah hukum. Setiap hukum dan putusan hakim seharusnya memberikan kepastian hukum, rasa keadilan dan mempertimbangkan asas kemanfaatan bagi warga negaranya. Tujuan dari setiap aturan dan tindakan hukum adalah untuk memberi kepastian hukum sehingga tidak terjadi kebimbangan, keraguan ataupun kecemasan pada warga. ${ }^{25}$ Pasal $28 \mathrm{D}$ ayat 1 UUD 1945 menegaskan agar hukum Negara member jaminan perlindungan, kebutuhan akan adanya kepastian hukum yang adil dan juga kebutuhan akan perlakuan yang sama. Dalam kepastian hukum, warga akan merasa nyaman dan terlindungi. Kepastian hukum tercipta jika tidak ada aturan yang bertentangan satu sama lain. ${ }^{26}$

Selanjutnya kepastian hukum dibutuhkan untuk menjamin keadilan di tengah masyarakat. Ketidakpastian hukum cenderung menyebabkan terjadinya ketidakadilan sebab mahkota dari hukum adalah keadilan. Hukum haruslah

25 Wantu M. Fence "Kendala Hakim Dalam Menciptakan Kepastian Hukum, Keadilan dan Kemanfaatan di Peradilan Perdata". Mimbar Hukum. 25 No. 2(2013): 205 - 218

26 Aden Ahmad Sihabudin \& Siti Hamidah. "Kepastian Hukum Surat Keterangan Waris Sebagai Persyaratan Pengambilan Jaminan Kredit”. Jurnal Selat. 6 No. 1(2018): 2354-8649 
mencerminkan peran negara dalam menjembatani semua kepentingan warganya.Negara hadir agar tercipta asas kesamaan, rasa hormat dan perhatian. ${ }^{27}$

Selain itu, jika melihat hukum agama sebagai hukum ilahi yang sifatnya kudus karena berasal dari sumber ilahi (teologis dan biblis) maka ketika hukum ini dihadapkan dengan hukum manusiawi (dalam hal ini hukum yang dibuat manusia, hukum negara, hukum sipil) maka juga menjadi penting adalah bagaimana memandang relasi antara yang ilahi dan manusiawi. Maka bisa saja, dari segi agama, hukum sipil atau hukum manusia adalah sebuah tantangan bagi hukum agama atau hukum ilahi. Hal ini bukan perkara mudah untuk didamaikan.

\section{PENUTUP}

\subsection{Kesimpulan}

Indonesia adalah negara hukum dan olehnya negara harus memastikan adanya kepastian hukum bagi setiap warganya. Kepastian hukum menuntut adanya unifikasi hukum. Karenanya pemerintah Indonesia telah berusaha melakukan penyusunan hukum yang dapat mengakomodir kepentingan semua kelompok. Salah satunya adalah Undang-undang No 1 Tahun 1974 tentang perkawinan. Penelitian ini menyimpulkan bahwa ada perbedaan yang mendasar antara Hukum Perkawinan Sipil dalam hal ini menurut Undang-undang Republik Indonesia Nomor 1 tahun 1974 dengan Kitab Hukum Kanonik dalam pandangan mengenai perkawinan dan perceraian. Perbedaan ini menyebabkan ada halangan dan tantangan bagi pasangan yang menikah secara Katolik dan kemudian bercerai secara sipil. Sebagai konsekuensi lanjut, pasangan kerap kali tidak mendapat perlindungan hukum dan bahkan mengalami ketidakadilan.

Konsekuensi lain dari perbedaan ini bukan hanya pengalaman personal pasangan yang telah menikah secara agama (Katolik) tetapi juga pada pertanyaan mengenai hukum ilahi (Gereja) yang ditantang oleh hukum manusiawi (hukum sipil). Maka aspek perkawinan yang sifatnya sakral juga turut ditantang dalam perjumpaannya dengan hukum perkawinan yang sifatnya manusiawi. 


\subsection{Saran}

Maka untuk menghilangkan masalah ketidakadilan tersebut, direkomendasikan agar 1) para hakim sebaiknya berkordinasi dengan pengadilan agama dalam Gereja Katolik dalam urusan perceraian perkawinan; 2) Undang-undang No 1 tahun 1974 tentang perkawinan segera direvisi agar menghasilkan hukum perkawinan negara yang sungguh-sungguh mengakomodir kepentingan hukum masing-masing agama kecuali kalau hukum tersebut melawan prinsip HAM dan keadilan.

\section{DAFTAR PUSTAKA}

Aden Ahmad, Sihabudin \& Siti Hamidah. "Kepastian Hukum Surat Keterangan Waris Sebagai Persyaratan Pengambilan Jaminan Kredit." Jurnal Selat 6, no. 1 (2018): 2354-8649.

Akbar Dhani, Indrawan. "Tinjauan Hukum dan Peran Pemerintah Dalam Tindak Pidana Perdagangan Orang (TPPO) di Kabupaten Karimun dan Kota Batam." Jurnal Selat 5, no. 2 (2018): 2354-8649.

Alkitab Deutrokanonika, Lembaga Biblika Indonesia.

Arliman, Laurentius S. "Perkembangan dan Dinamika Hukum Ketenagakerjaan Di Indonesia." Jurnal Selat 5, no. 1 (2017): 2354-8649.

Asnawi, Shulton Habib. "Hak Asasi Manusia Islam dan Barat: Studi Kritik Hukum Pidana Islam dan Hukuman Mati.Supremasi Hukum." Supremasi Hukum 1, no. 1 (2012): 25-48.

Faradz, H. "Tujuan dan Manfaat Perjanjian Perkawinan." Jurnal dinamika Hukum 8, no. 3 (2008).

Fathur, Alfa Rahman. "Pernikahan Dini dan Perceraian di Indonesia." JAS: Jurnal Ilmiah Ahwal Syakhshiyyah 1, no. 1 (2019): 49-56.

Fence, Wantu M. "Kendala Hakim Dalam Menciptakan Kepastian Hukum, Keadilan dan Kemanfaatan di Peradilan Perdata." Mimbar Hukum 25, no. 2 (2013): 205 218.

Kitab Hukum Kanonik (Codex Iuris Canonici) . Jakarta: Konferensi Waligereja , 1983.

Lathifah, Itsnaatul. "Pencatatan Perkawinan: Melacak Akar Budaya Hukum dan respon Masyarakat Indonesia terhadap Pencatatan Perkawinan." Jurnal Pemikiran Hukum 3, no. 1 (2015).

Lon, S. Yohanes. Hukum Perkawinan Sakramental dalam Gereja Katolik. Yogyakarta: PT Kanisius, 2019. 
Lon, S. Yohanes, and Fransiska Widyawati. "Bride-Wealth: Is There Respect for Women in Manggarai?" Humaniora 30, no. 3 (2018): 271-278.

Lon, Yohanes S. "Increasing the Knowledge and Awareness of the People of Ruteng Diocese in Canon Law." Randang Tana-Jurnal Pengabdian kepada Masyarakat 2, no. 1 (2019): 1-9.

Lumme, Andreas. "Norma Hukum Agama Katolik di Bidang Perceraian dan Konflik Penerapannya di Pengadilan Bagi Suami Isteri." Jurnal Hukum Pro Justisia 25, no. 2 (2007).

Nyoman, Dewi Riana, and Hilda Sudhana. "Hubungan Antara Komunikasi Interpersonal Pasutri dengan Keharmonisan dalam Pernikahan." Jurnal Psikologi Udayana 1. No. 1, 2013: 22-31.

Undang-undang Republik Indonesia No 1 tahun 1974 tentang Perkawinan.

Widyawati, Fransiska. Catholics in Manggarai, Flores, Eastern Indonesia. Geneva: Globethics.net, 2018. 